\title{
WPS4061
}

\section{Access to Financial Services in Zambia}

\author{
José de Luna Martínez*
}

\begin{abstract}
Despite the deep financial sector reforms undertaken in Zambia in the early 1990s, the expected benefits of establishing a market-based banking system have not materialized yet. In 2005, the banking system continued to be small and under-developed. Credit to private sector by banks represented only $8 \%$ of GDP in 2005, which is slightly lower than the level registered in 1990 . As in the early 1990s, only large corporations and a few small and medium enterprises have access to credit in 2006. Moreover, less than 8\% of Zambia's adult population had a bank account in 2005. Furthermore, despite the policy of open doors to foreign financial institutions, which has been in place since Zambia's independence, only a few new banking products have been introduced by foreign banks to serve the needs of households and firms. This paper analyzes the factors that have prevented the development of a large and inclusive banking system in Zambia and highlights possible actions that may help improve access to finance in Zambia in both the short and long terms.
\end{abstract}

\section{World Bank Policy Research Working Paper 4061, November 2006}

The Policy Research Working Paper Series disseminates the findings of work in progress to encourage the exchange of ideas about development issues. An objective of the series is to get the findings out quickly, even if the presentations are less than fully polished. The papers carry the names of the authors and should be cited accordingly. The findings, interpretations, and conclusions expressed in this paper are entirely those of the authors. They do not necessarily represent the view of the World Bank, its Executive Directors, or the countries they represent. Policy Research Working Papers are available online at http://econ.worldbank.org.

\footnotetext{
* José de Luna Martínez is a Senior Economist at the Finance and Private Sector Development Vice Presidency of the World Bank. Comments on this paper are welcome. They can be sent to the author's email address: Jdelunamartinez@worldbank.org
} 


\section{Table of Contents}

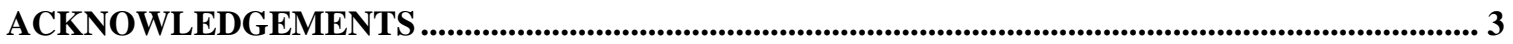

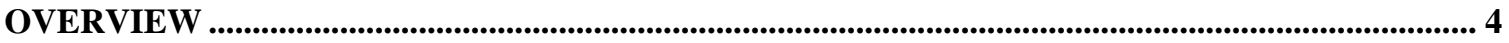

1. REFORMS AND ACCESS TO BANKING SERVICES IN ZAMBIA.............................................. 8

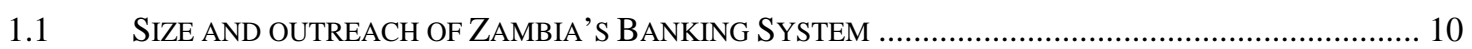

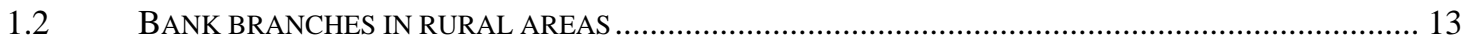

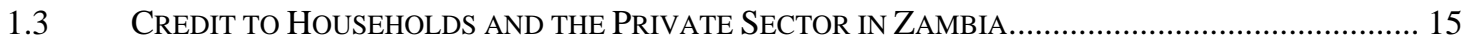

1.4 ROLE OF MICRO-FINANCE INSTITUTIONS (MFIS) IN ZAMBIA ........................................... 17

2. WHY HAS LIBERALIZATION NOT DELIVERED BENEFITS? .............................................. 19

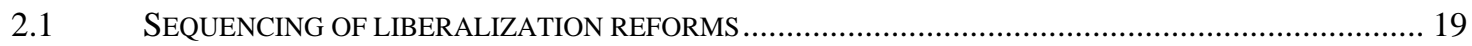

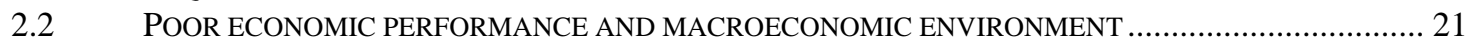

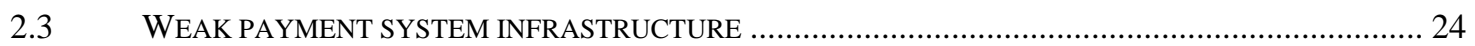

2.4 DEFICIENCIES IN THE LEGAL, REGULATORY AND JUDICIARY FRAMEWORK.............................. 25

2.5 NEED TO ADAPT PRUDENTIAL REQUIREMENTS TO ZAMBIA’S NEEDS.................................... 26

3. PRO-ACTIVE POLICIES TO PROMOTE ACCESS TO FINANCIAL SERVICES........................ 30

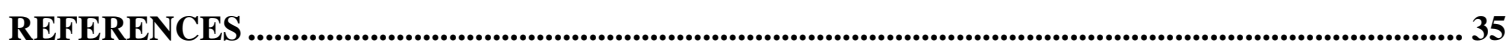

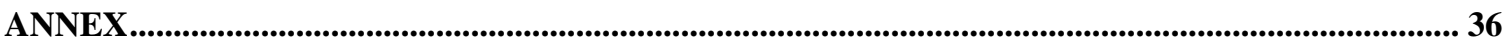




\section{Acknowledgements}

This paper was prepared as part of a pilot project conducted by the World Bank to analyze the state of trade and services liberalization in Zambia. The author is grateful to Aaditya Mattoo, Task Manager of this project, for his valuable comments and observations on this report, and Latifah Merican, for sharing her knowledge on financial sector liberalization and encouraging the publication of this report. The author also thanks the following colleagues for their useful comments on earlier versions of the report: Lucy Payton, Ahmet I. Soylemezoglu, Antony Thompson, and Thorsten Beck. Special thanks are due to Sam Maimbo who facilitated many of the meetings with financial institutions and authorities in Zambia and also provided valuable comments on the report. Last, but not least, the author expresses its gratitude to all people in Zambia that contributed to this project by sharing their knowledge, and providing the data and information to prepare this report. 


\section{OVERVIEW}

In the early 1990s, Zambia fully liberalized transactions on the capital account and undertook a series of reforms to promote a market-based financial system, which encouraged the entry of new domestic banks and led to the expansion of existing foreign banks. Zambia allows not only foreign investment in banking, but also allows firms and individuals to borrow from and place deposits abroad. At the end of 1995, six foreign banks accounted for $67 \%$ of assets, $76 \%$ of loans, and $64 \%$ of deposits in the banking system. Large firms raise a significant proportion of their long term capital needs from abroad, and around one-fifth of the commercial banks' assets are placed abroad.

However, the benefits expected from an open, private, and largely foreign-owned banking system have not so far materialized and access to banking services is low and unequal. Credit to the private sector by banks represented only 8\% of GDP in 2005, which is lower than the level registered in 1990 . Only 5,000 people hold 90\% of loans. Just $8 \%$ of Zambia's adult population had a bank account in 2005, one of the lowest ratios in Sub-Saharan Africa. The number of rural branches of banks actually declined in the last decade by 15 percent to 65 . Whereas micro-finance institutions have grown rapidly in some other Sub-Saharan countries, in Zambia they serve only 50,000 customers which is $0.005 \%$ of the population.

Access to bank credit is not just scarce, it is also extremely expensive. The average annual interest rate on loans was 48\% in 2005 (the inflation rate was 20\%). Large firms and exporters borrow at rates below the average (the prime rate was $20 \%$ in 2005). The few small and medium enterprises (SMEs) in Zambia that are able to borrow from banks pay the average annual lending rate or higher. Microfinance institutions lend at rates of around 50-60 per cent. Most loans have a short-term maturity (1-3 months); there are only few loans with a maturity of 1 year or more. The few firms with sources of revenue in foreign currency are able to obtain financing from banks in US dollars at significantly lower interest rates.

Bank savings and deposits accounts are not a practical instrument for building savings over time. No interest at all is paid on small savings accounts denominated in Kwacha and only large firms receive positive interest rates on their deposits. A 320,000 Kwacha deposit (equivalent to US\$100) today would lose two thirds of its real value after 6 years if during this period the annual inflation rate remains at $18 \%$. In addition to this, monthly charges are also deducted by all banks. Five of the thirteen banks require customers to have a minimum balance of $\$ 156$ to $\$ 313$ dollars or more to open a savings account. In five other banks the minimum balance to open an account is lower; it is in the range of $\$ 16$ to $\$ 78$ dollars. However, in the context of Zambia, where 58\% of the population lives on less than one dollar a day, these minimum balances prevent most people from having access to basic banking services. Thus, with the exception of highincome households, public servants and employees of large companies, most Zambians do not have access to products offered by banks. 
Macroeconomic and institutional problems are the main reasons why liberalization has not delivered significant benefits and they are being gradually remedied. The large fiscal deficit (which amounted to 6\% of GDP in 2003, but has been reduced to 2.3\% of GDP today) has been financed by borrowing from banks, which has limited the funds available to finance the private sector. The recent reduction in the fiscal deficit and government borrowing has shaken the banks out of their stupor and immediately induced stronger efforts to lend to the private sector. In addition there are key institutional weaknesses that undermine the effectiveness of the banking sector: $90 \%$ of land is still collectively owned, making it difficult for individuals to produce collateral; past disbursement by state banks of credit as de facto grants has created a tradition of default; and the judicial system provides few effective procedures to collect delinquent loans. The credit bureau being set up by the Bankers' Association is a critical step to improve market information and to strengthen the credit culture. The current plan is to start the credit bureau with negative information on defaulters. That effort should be supported and expanded as soon as technical feasible to include positive information to help clients with a clean credit history enjoy the expanding services and lower costs. Over time, an attempt should be made to extend the credit bureau database to small- and medium-sized firms that suffer from severe information asymmetries in the Zambian markets.

But limited access is also attributable to financial policy failures, beginning with an inappropriate sequence of reform that has had durable consequences. The financial system was liberalized before establishing a new legal and regulatory framework for the banking system that would encourage prudent risk-taking and market discipline. Ten new bank licenses were issued between 1991 and 1994 increasing the number of commercial banks to 18, and there were nine bank failures between 1995 and 2001 estimated to have caused losses to taxpayers and depositors equivalent to 7 percent of GDP. At the end of 2005, non-performing loans in the banking system still amounted to $8.9 \%$ of total loan portfolio. All banks scaled back their lending operations and increasing their holding of government securities, which offered high yields at a lower risk for banks. Barclays, the largest bank in Zambia, refrained from any new lending for various years and is starting to lend again only in 2006.

In recent years there have been significant improvements in the regulatory framework, but some weaknesses remain. Following the first episodes of bank failures in 1995, Zambia put in place major measures to improve the quality of bank regulation and supervision, and in 2002, the Financial Sector Assessment Program (FSAP) carried out by the IMF and World Bank found that Zambia satisfactorily complies with many of the the Basel Core Principles on Bank Supervision. Of the 30 principles assessed under the BCPs, Zambia was found to be compliant or largely compliant with 19 principles and non-compliant or materially non-compliant with 11 principles. Major weaknesses were found in the areas of independence of the central bank, remedial measures to deal with insolvent banks, management and control of market risks, internal controls, and antimoney laundering. Following the release of the FSAP report, Zambian authorities drafted a comprehensive Financial Sector Development Plan (FSDP) which contains a series of actions for the period 2004-2010 to strengthen the overall financial system. 
Bank regulation in Zambia must be sensitive to the needs of the population if banks are to be encouraged to lend to the poor and SMEs and, in particular, if microfinance institutions are brought under the umbrella of Bank of Zambia supervision. International regulation, such as AML, if applied with no discretion, is not well designed for countries in which only $10 \%$ of land is registered and much of the population live in temporary dwellings and work informally. ${ }^{1}$ Most small and medium enterprises are not registered, do not pay taxes, and do not have audited accounts and, therefore, can not access financial services offered by banks. Banks in the past have relied on group monitoring and personalized relations in order to give loans for productive investments carried out by this part of the population and required only a national identity card. However, "Know You Customer" rules make such lending illegal if the customer cannot provide documentary proof of residence or proof of employment in the formal sector. Several bank managers told us that these rules were effectively hindering them from making loans to SMEs and individuals that they would usually have made. Finally, there is a proposal to regulate microfinance institutions which could have the benefit of protecting depositors, enhance stability, and help mobilize resources from both donors and the formal sector, but must not inhibit the development of this nascent sector.

The disappearance of past, inefficient instruments of providing the poor with access to financial services left a socially costly vacuum that is only now being addressed. Before liberalization, policy-makers played an active role in promoting access to finance through the direct control of financial markets and financial institutions, subsidies and credit allocation. During the '90s policy-makers refrained from any such intervention in the financial system with the expectation that foreign and private financial institutions would increasingly serve all segments of the population and private sector. It has now become clear that there is a need for the visible hand of the government to use market friendly instruments to promote access in the short run, while the fruits of ongoing institutional and fiscal reform are still unripe. It should be noted, that government attempts to increase access have more often than not failed to achieve their objectives. Subsidized credit, for example for housing, has typically ended up benefiting the middle class and those who would have had access to credit in any case. Experience from other countries suggests that interventions to widen access are most likely to succeed if they harness market forces by providing incentives to public or commercial banks to innovate and to engineer products which allow downscaling to serve the poor to be both profitable and sustainable. The example of South Africa underlines that "moral suasion" on the part of the government can encourage banks to act collectively to profitably meet universal access goals. If the costs of extending services remain prohibitive for commercial banks, there might be a case for government intervention to provide market infrastructure, for example, by renting out space in the post offices to banks that wish to expand into rural areas, or subsidizing transaction costs. Any such intervention, however, is unlikely to succeed if it distorts competition in the sector and awards subsidies in a non-competitive way.

\footnotetext{
${ }^{1} 90 \%$ of the workforce is estimated to work in the informal economy.
} 
There is little cost and perhaps some benefits from multilateral commitments, and greater benefit but little prospect of deeper regional integration through regulatory harmonization. Given the openness of the Zambian banking sector, and the fact that most of the desired policy interventions do not require either impeding market access or discriminating against foreign banks, there is little cost to Zambia to bind existing openness under the GATS. There may be some benefit in so far as such bindings create greater regulatory certainty and hence make the market more attractive to new entrants and more contestable. Creating a more integrated regional market through regulatory harmonization would unquestionably help Zambia overcome some of the disadvantages of its small market size but there seems little willingness at this point to make the necessary sacrifice in regulatory autonomy.

Through international engagement Zambia can mobilize financial and technical support to develop more appropriate regulations and for universal access policies. Zambia could request:

- Assistance with the continued implementation of the FSDP and long term institutional and capacity building.

- Assistance and continued support for the creation of the credit information bureau.

- Assistance with the evaluation and implementation of banking regulation in light of access needs.

- Assistance in the assessment of and implementation of pro-active universal access policies. 


\section{Reforms and Access to Banking Services in Zambia}

In 1992, Zambia began to deregulate its financial sector and implement a series of economic reforms aimed at establishing the foundations of a market-based economy. In that year, borrowing and lending rates were deregulated and the exchange rate was permitted to be market determined. ${ }^{2}$ By March 1993 most foreign exchange controls on current transactions had been removed and in February 1994 the capital account of the foreign payment systems was liberalized. In 1995, the Bank of Zambia allowed commercial banks to hold foreign currency deposits. In 1996 the final phase of liberalization of the foreign exchange market was implemented with Zambia Consolidated Copper Mines (ZCCM) being allowed to retain all its foreign currency earnings and supply foreign exchange to the market directly.

The liberalization process of the 1990s led to a deep reconfiguration of the Zambian banking system. Before liberalization, the banking system was composed by a group of public and privately-owned domestic banks holding approximately $60 \%$ of the assets of the banking system. A group of foreign banks held the remaining $40 \%$ of the assets. Between 1992 and 1994, ten new banks were established by domestic private investors. However, these new banks, along with other domestic banks, failed in the subsequent years for reasons discussed below. As a result, existing foreign banks progressively increased their market share in Zambia. ${ }^{3}$ While in the early 1990s the combined assets of foreign-owned banks did not represent more than $40 \%$ of the banking system assets, at the end of 2005 seven foreign banks - Barclays, Standard Chartered, Stanbic, Finance Bank, Citibank, Bank of China and Indo-Zambia Bank -- held 73\% of total assets. Moreover, in 2005 foreign banks had 79\% of the total lending portfolio, 69\% of the deposits in the banking system and they operated 91 of the existing 156 bank branches in Zambia.

\footnotetext{
${ }^{2}$ Since independence, the foreign exchange market has undergone various changes. From 1964 through the early 1980s, the foreign exchange market was characterized by administrative controls, with the Kwacha firstly being pegged to the US dollar then later to the Special Drawing Rights. In the 1980s through the 1990s, the exchange rate was determined by a quasi-market system and later by a Foreign Exchange Committee. The market was finally liberalized in 1992.

${ }^{3}$ Foreign banks have operated in Zambia uninterruptedly since the early 1900s. Even during the phase of nationalization of strategic sectors in the 1970s, foreign banks remained untouched.
} 
Table 1. Banking Institutions in Zambia in 2006

\begin{tabular}{|c|c|c|c|c|c|c|c|c|}
\hline \multirow[b]{2}{*}{ Commercial Banks } & \multicolumn{2}{|c|}{ Total Assets } & \multicolumn{2}{|c|}{ Loans and advances } & \multicolumn{2}{|c|}{ Deposits } & \multicolumn{2}{|c|}{ Branches } \\
\hline & Assets & $\%$ of total & Loans and advar & $\%$ of total & Deposits & $\%$ of total & branches & $\%$ of total \\
\hline \multicolumn{9}{|l|}{ Foreign banks } \\
\hline 1. Barclays Bank & $1,587,948$ & $20 \%$ & 750,489 & $32 \%$ & 988,120 & $18 \%$ & 17 & $11 \%$ \\
\hline 2. Standard Chartered & $1,214,629$ & $16 \%$ & 344,322 & $15 \%$ & 967,324 & $18 \%$ & 15 & $10 \%$ \\
\hline 3. Stanbic Bank & $1,122,275$ & $14 \%$ & 414,368 & $18 \%$ & 735,346 & $13 \%$ & 9 & $6 \%$ \\
\hline 4. Finance Bank Zambia Ltd & 604,535 & $8 \%$ & 174,556 & $8 \%$ & 384,176 & $7 \%$ & 38 & $24 \%$ \\
\hline 5. Citibank Zambia Ltd & 560,095 & $7 \%$ & 80,710 & $3 \%$ & 338,161 & $6 \%$ & 2 & $1 \%$ \\
\hline 7. Indo-Zambia Bank & 453,116 & $6 \%$ & 71,532 & $3 \%$ & 314,287 & $6 \%$ & 9 & $6 \%$ \\
\hline 6. Bank of China & 112,117 & $1 \%$ & 109 & $0 \%$ & 93,123 & $2 \%$ & 1 & $1 \%$ \\
\hline Subtotal & $5,654,715$ & $73 \%$ & $1,836,086$ & $79 \%$ & $3,820,537$ & $69 \%$ & 91 & $58 \%$ \\
\hline \multicolumn{9}{|l|}{ Domestic banks } \\
\hline 8. African Banking Corporation & 124,314 & $2 \%$ & 68,539 & $3 \%$ & 31,240 & $1 \%$ & 1 & $1 \%$ \\
\hline 9. Cavmont Merchant Bank & 72,510 & $1 \%$ & 6,381 & $0 \%$ & 58,836 & $1 \%$ & 11 & $7 \%$ \\
\hline 10. First Alliance Bank & 110,884 & $1 \%$ & 21,074 & $1 \%$ & 58,343 & $1 \%$ & 4 & $3 \%$ \\
\hline 11. Intermarket Banking Corporation & 87,108 & $1 \%$ & 21,292 & $1 \%$ & 70,170 & $1 \%$ & 2 & $1 \%$ \\
\hline 12. Investrust Bank & 197,333 & $3 \%$ & 80,109 & $3 \%$ & 162,912 & $3 \%$ & 5 & $3 \%$ \\
\hline 13. Zambia National Commercial Bar & $1,537,857$ & $20 \%$ & 278,552 & $12 \%$ & $1,297,752$ & $24 \%$ & 42 & $27 \%$ \\
\hline Subtotal & $2,130,006$ & $27 \%$ & 475,947 & $21 \%$ & $1,679,253$ & $31 \%$ & 65 & $42 \%$ \\
\hline Total & $7,784,721$ & $100 \%$ & $2,312,033$ & $100 \%$ & $5,499,790$ & $100 \%$ & 156 & $100 \%$ \\
\hline
\end{tabular}

Source: Bank of Zambia

Among the group of seven foreign banks, three large banks - Barclays, Standard Chartered and Stanbic Bank -- play a dominant role in Zambia's financial system. They hold $50 \%$ of assets in the banking system, $55 \%$ of the total loan portfolio, $49 \%$ of deposits, and $27 \%$ of all branches. ${ }^{4}$

Nowadays the banking system is not only dominated by foreign-owned banks, but also shows strong signs of soundness and profitability. According to data from the Bank of Zambia, at the end of 2005 all the 13 commercial banks operating in Zambia reported a capital adequacy ratio above the minimum level of $8 \%$ on risk-weighted assets and a moderate level of non-performing loans, $8.9 \%$ of total lending portfolio. In addition, in 2005, banks recorded high profits that allowed them to achieve a $7.4 \%$ annual return on assets. ${ }^{5}$

\footnotetext{
${ }^{4}$ Of the remaining seven banks, the Zambia National Commercial Bank - a state-owned bank -is the second largest institution operating in Zambia, with $20 \%$ of the banking system assets. Five other banks owned by local investors -- African Banking Corporation, Cavmont Merchant Bank, First Alliance Bank, Intermarket Banking Corporation, and Investrust Bank- hold together 8\% of the banking system assets. Finally, one bank, the Indo Zambia Bank is a joint venture between the Governments of Zambia and India and holds the remaining 6\% of the banking system assets.

${ }^{5}$ In addition to commercial banks, the financial sector comprises non-bank financial institutions (comprising the three building societies, some micro finance institutions, the National Savings and Credit Bank (NSCB), the DBZ, 37 Bureau de changes and leasing companies), insurance companies, pension funds and the capital markets.
} 


\subsection{Size and outreach of Zambia's Banking System}

Despite the profound reform efforts undertaken by authorities, the growing presence of foreign-owned banks in Zambia, and the soundness and profitability of the banking sector as a whole, the banking system remains small and under-developed. At the end of 2005, total assets of the banking system amounted to only US\$ 1.7 billion dollars, which represented 35\% of Zambia's GDP. Other ratios on the size of the financial system indicate that the system has remained small since liberalization. For example, the ratio of M2 to GDP reached 22\% in 2004, which is the same level of 1990, the year when reform measures were implemented, as illustrated in the following figure.

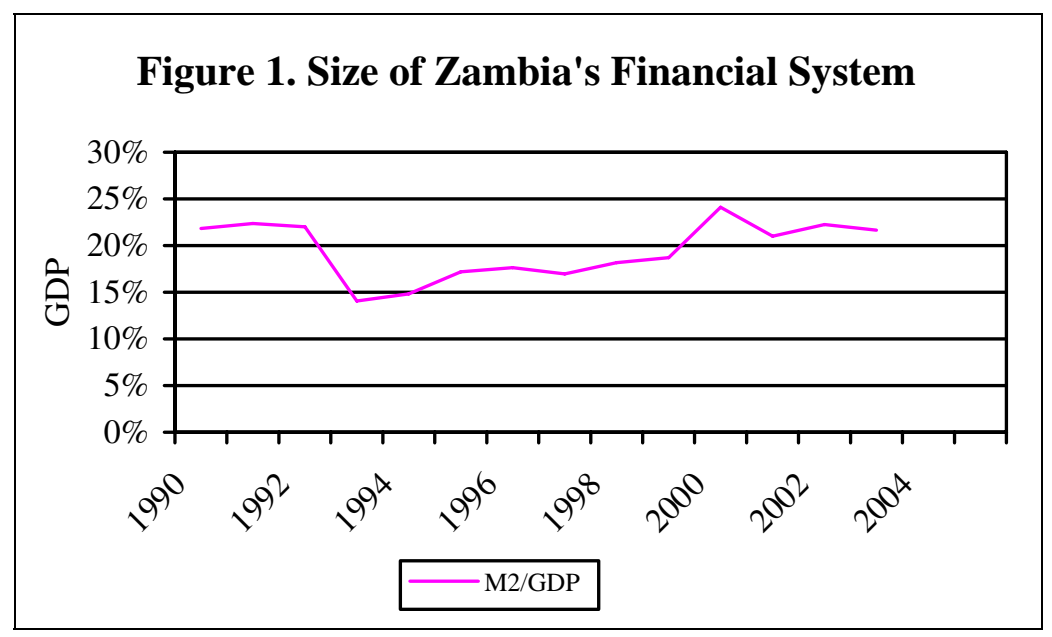

Commercial banks in Zambia are small and serve only a small segment of the population and private sector. Five of the thirteen banks have less than $\$ 5$ million in capital each, seven banks have capital in the range of $\$ 5$ to $\$ 30$ million dollars, and only one bank (Barclays) has a capital of \$52 million dollars.

At the end of 2005, there were 405,888 deposit accounts at all commercial banks in Zambia (including deposit accounts in both Kwacha and foreign currency). This number is extremely low for a country with a population of 10.5 million people, which include six million persons aged 18 and above. The above figures indicate that on average only $3.8 \%$ of the population, or $6.2 \%$ of the people aged 18 and above, have a bank account (putting aside the fact that the figures include accounts by firms and some people may have more than one account). The ratio of bank accounts to population is one of the lowest in Sub-saharan Africa, as illustrated in the following figure. 
Figure 2. Percent of Population with a Bank Deposit Account in Africa

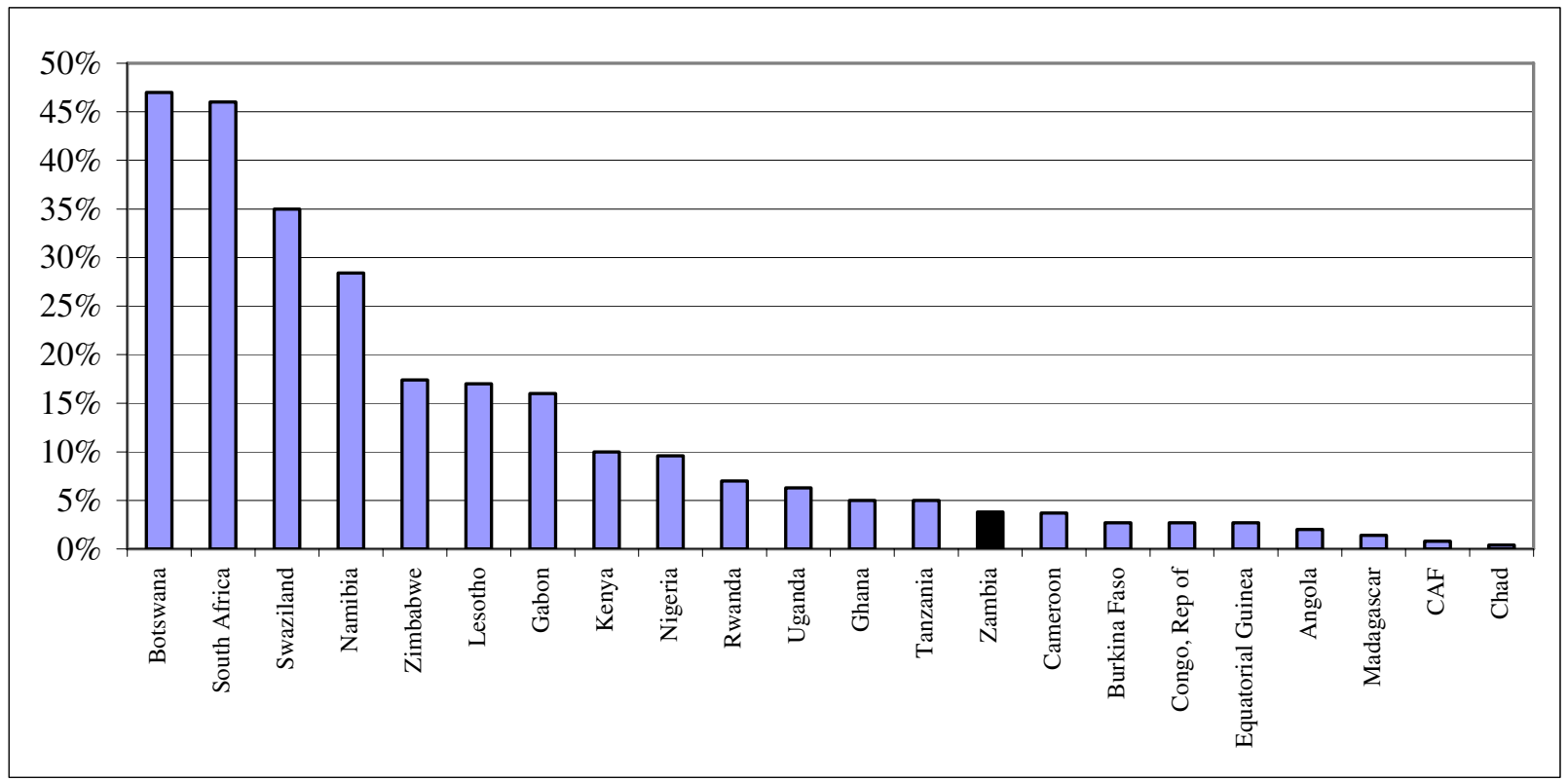

Source: Beck, Demirguc-Kunt, and Peria (2005) and data from commercial banks in Zambia

As shown in the following figure, 64\% of the accounts at banking institutions in Zambia have a balance below Kwacha 320,000 or $\$ 100$ dollars, $8 \%$ of the accounts have a balance between Kwacha 320,000 (\$100) and 640,000 (\$200 dollars), and the remaining $28 \%$ have balances above Kwacha 640,000 (\$200 dollars). In terms of value of deposits, $10 \%$ of account holders (42,000 accounts) have $85 \%$ of total deposits in the Zambian banking system. 
Figure 3. Distribution of Bank Deposits in Zambia in March 2006

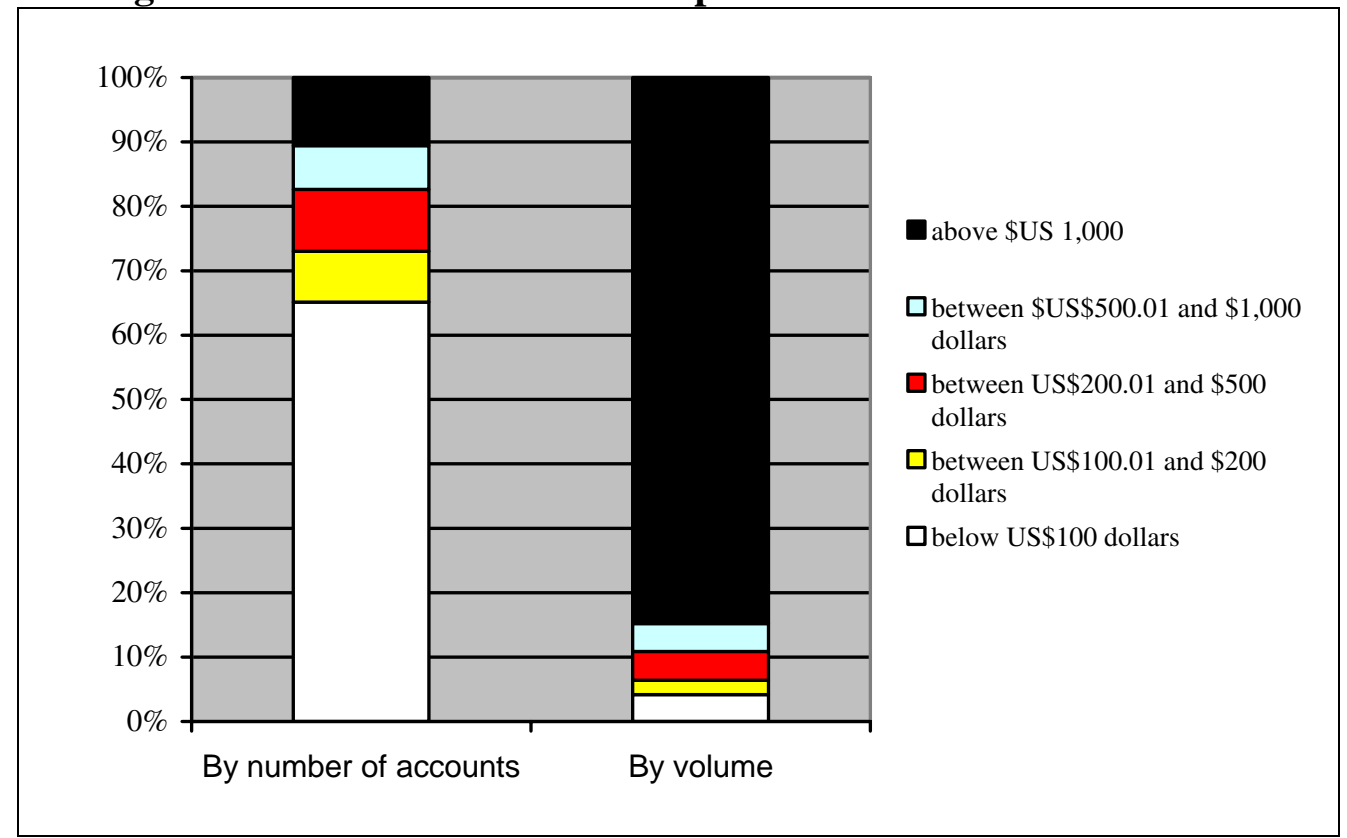

Source: Data from commercial banks in Zambia

Several studies indicate that the account holders are usually people living in urban areas and with a regular employment in the public sector or a large private firm. One additional characteristic is that the real value of small savings and deposit accounts declines over time, as no interest is usually paid on small savings accounts denominated in Kwacha. Only large firms receive positive interest rates on their deposits. In practice, for most households in Zambia bank savings and deposits are just a way to safeguard coins and notes, not a practical instrument to save money over time. As illustrated in the following figure, a 320,000 kwacha deposit (equivalent to $\$ 100$ dollars) today would lose two thirds of its real value after 6 years if during this period the annual inflation rate remains at its 2004 level (18\%) and no nominal interest is paid, as is currently the case for small saving deposits in Kwacha.

Figure 4. Real Value of a 320,000 Kwacha Deposit*

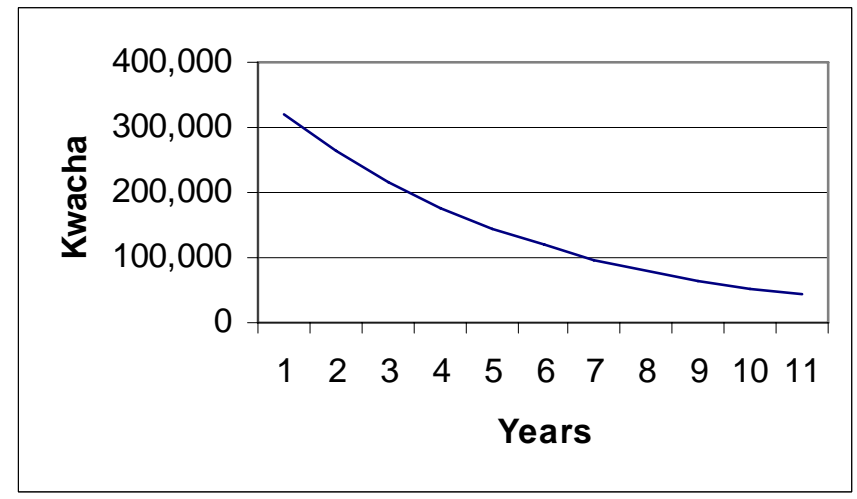

*It assumes an annual inflation rate of $18 \%$ and no interest payments. 
In addition to the lack of interest payments on small saving deposits in Kwacha, most commercial banks in Zambia have adopted high balances to open or maintain an account, making it impossible for most people to have a savings or deposit account. As illustrated in the following table, five banks require customers a minimum balance of \$16 to \$78 dollars to open a savings accounts. In a group of five other banks, the minimum balance to open an account ranges from \$156 to \$313 dollars. In the context of Zambia, where $71 \%$ of the population lives on less than one dollar a day, the minimum balances currently required by banks are high and prevent most people from having access to basic banking services.

Table 2. Minimum Balances to Open and Maintain a Bank Account in March 2006

\begin{tabular}{|c|c|c|c|c|}
\hline \multirow[t]{2}{*}{ BANK } & \multicolumn{2}{|c|}{ Account Opening Balance } & \multicolumn{2}{|c|}{$\begin{array}{c}\text { Minimum balance to avoid } \\
\text { penalty }\end{array}$} \\
\hline & Kwacha & US\$ & Kwacha & US\$ \\
\hline African Banking Corporation Zambia & 500,000 & $\$ 156$ & 500,000 & $\$ 156$ \\
\hline Bank of China & $1,000,000$ & $\$ 313$ & $1,000,000$ & $\$ 313$ \\
\hline Barclays Bank & N/A & N/A & N/A & N/A \\
\hline Cavmont Capital & $1,000,000$ & $\$ 313$ & N/A & N/A \\
\hline Citibank & N/A & N/A & N/A & N/A \\
\hline Finance Bank & 100,000 & $\$ 31$ & 50,000 & $\$ 16$ \\
\hline First Alliance Bank & 250,000 & $\$ 78$ & 250,000 & $\$ 78$ \\
\hline Indo Zambia Bank & 150,000 & $\$ 47$ & 250,000 & $\$ 78$ \\
\hline Intermarket Banking Corporation & $1,000,000$ & $\$ 313$ & 250,000 & $\$ 78$ \\
\hline Investrust & 50,000 & $\$ 16$ & 50,000 & $\$ 16$ \\
\hline Stanbic Bank & 50,000 & $\$ 16$ & N/A & N/A \\
\hline Standard Chartered & 750,000 & $\$ 234$ & 750,000 & $\$ 234$ \\
\hline Zambia National Commercial Bank & N/A & N/A & $\mathrm{N} / \mathrm{A}$ & $\mathrm{N} / \mathrm{A}$ \\
\hline
\end{tabular}

Source: Bank of Zambia (2006)

Interviews with bankers revealed that at this time most banks in Zambia do not seem to be interested in serving the low-income part of the population. Most banks prefer to target only a small universe of the population, approximately 500,000 people with medium to high level incomes, which is defined as the "bankable" group by the bankers themselves. Besides commercial banks, there are no other types of financial institutions offering savings and deposits in Zambia, which could serve the needs of low-income households not served by commercial banks. By law, the approximately 50 microfinance institutions that operated in Zambia in 2005 were not allowed to take deposits from the public.

\subsection{Bank branches in rural areas}

The limited access to banking services in Zambia is reflected in the low number of bank branches serving both urban and rural areas. While in 1990 there were 120 bank branches, in 2005 there were only 152, giving a ratio of one bank branch per 70,000 people in 2005, one of the lowest bank penetration ratios in the world. 
As can be seen in the following figure, the modest increase in the total number of bank branches can be mostly attributed to the growth of branches in urban areas. In 1990, 50\% of all branches were in urban areas and the other $50 \%$ in rural areas. This was in line with the government policy at the time. From 1990 to 2004, the number of bank branches increased to 152. However, with the removal of the requirement to open a rural branch for every urban branch opened, there was a reduction in the proportion of rural branches to urban branches, from $50 \%$ in 1990 to $43 \%$ in 2004 . The change is most notable in the period 1995 to 2000 when the number of urban branches increased by $16 \%$ to 79 from 68 compared to a drop of $15 \%$ to 65 from 77 branches in rural areas. ${ }^{6}$

Figure 5. Number of Bank Branches in Zambia (1990-2004)

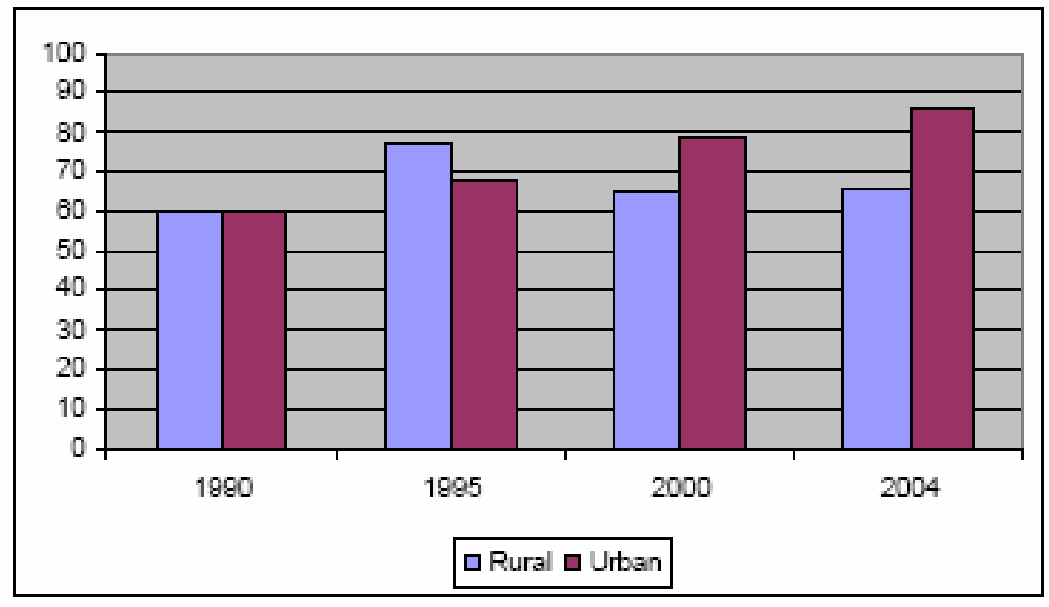

Source: Bank of Zambia

The concentration of financial institutions in urban areas has been attributed to the fact that Zambia's rural environment is not particularly conducive to the establishment of viable businesses. One of the main criteria used by banks in determining whether to establish a branch in a particular locality is the economic activity and level of business. The main form of economic activity in rural areas is peasant farming. Where there is commercial farming on a significant scale, the banks may still be inclined to serve potential clients from already existing branches in the nearest urban center, with visits to the client made when required.

The costs of operating in rural Zambia are relatively high. Like most other developing countries, Zambia also suffers from a lack of basic infrastructure in the rural communities. Electricity supply in outlying areas is unreliable and in some areas non existent. Telecommunications are poorly developed, making it difficult to communicate

${ }^{6}$ A better indicator of how well rural population is served by bank branches is the number of people living close to a branch. Unfortunately, that information was not available at the time of this study. In addition, the indicator of number of branches does not take into account whether former branches in rural areas were closed due to the decline of the population caused by migration to urban areas. 
with head office and other branches. This also adversely affects the smooth and efficient operation of a payment system. Much of the country is covered by gravel roads and where roads are paved, away from the main line of rail, they are in bad need of repair. All these factors contribute to significantly raising the costs of operating in these areas. In most cases, they prove prohibitive for investment into the provision of financial services.

\subsection{Credit to Households and the Private Sector in Zambia}

Access to credit remains extremely limited in Zambia. As illustrated in the following chart, between 1990 and 2004, bank credit to the private sector, measured as a percentage of GDP, dropped slightly from $8.8 \%$ to $8.1 \%$, while at the same time banks increased their holding of government securities.

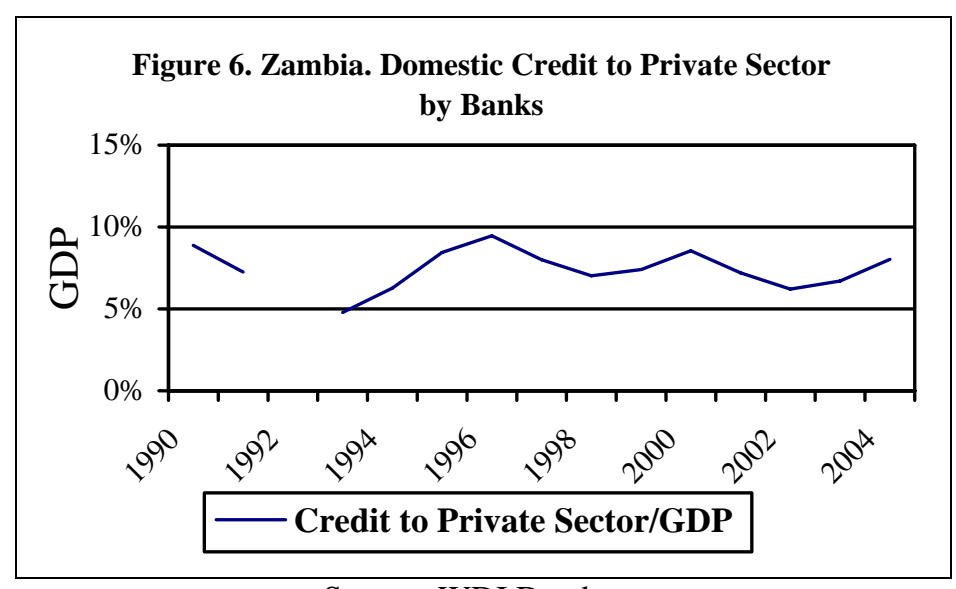

Source: WDI Database

The number of firms and households borrowing from banks in Zambia also remains extremely low. In 2005, authorities estimated that the total number of outstanding loan accounts amounted to only 46,908, which includes 39,074 of accounts for individual persons and the rest are accounts for firms, government entities, etc. In other words, this means that in Zambia only $0.37 \%$ of the population has a credit (or loan) account with a commercial bank.

As illustrated in the following figure, approximately $50 \%$ of all loan accounts are represented by credits and advances below $\$ 100$ dollars. ${ }^{7}$ It is interesting to note that only 5,687 borrowers (4,028 individuals and 1,659 firms) had loans that represented $91 \%$ of the total loan portfolio of commercial banks in Zambia, reflecting the high concentration of wealth in the country.

\footnotetext{
${ }^{7}$ The large number of loans below US $\$ 100$ dollars can be attributed to the large number of nonperforming loans that are still in the books of banks and which have become small over time.
} 
Figure 7. Distribution of Bank Loans and Advances in March 2006

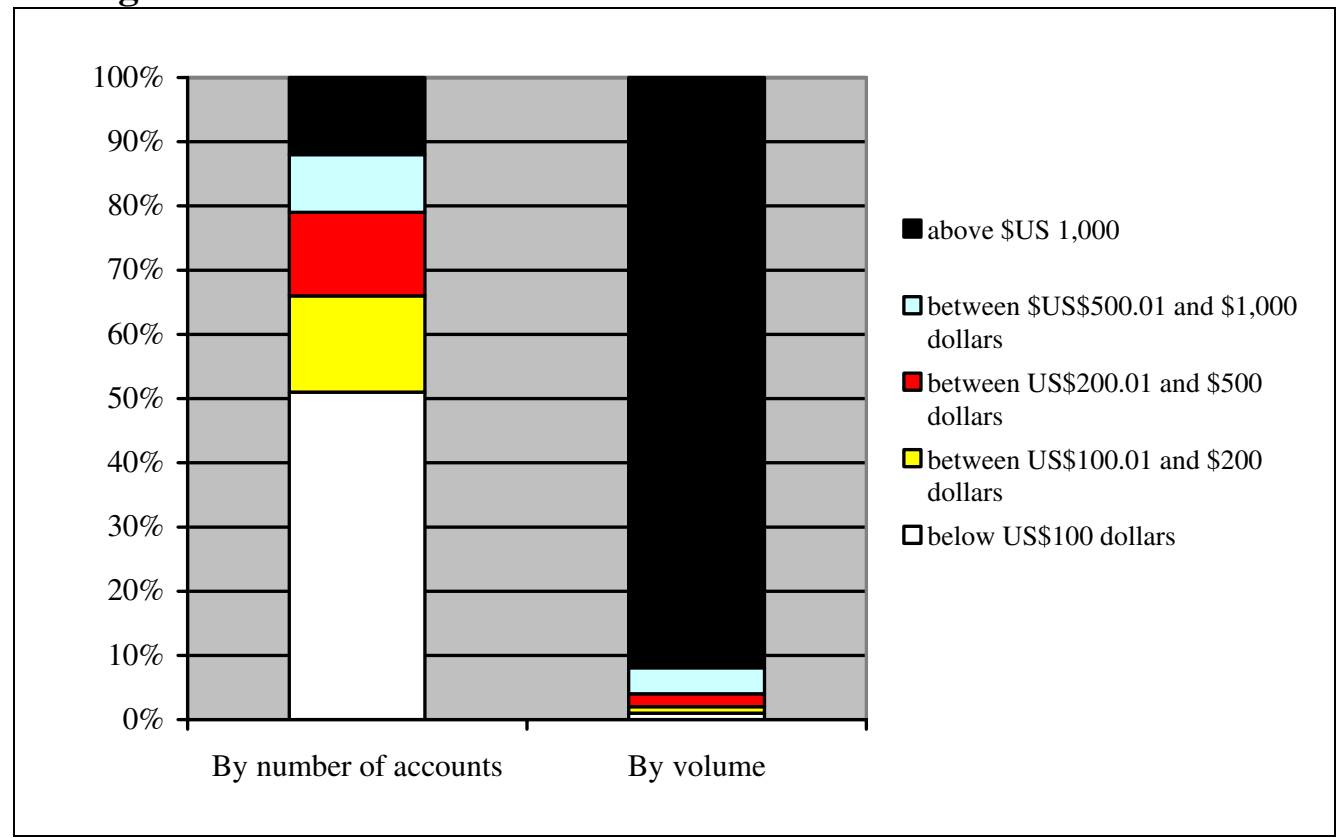

Source: Data from commercial banks in Zambia

In terms of volume, at the end of $200573 \%$ of the total loan portfolio of banks was composed of loans granted to private firms and the remaining $27 \%$ by loans granted to individuals and households. In the case of loans to private firms, $69 \%$ of credit is concentrated in the following sectors: agriculture, forestry and fishing, wholesale and retail trade and manufacturing.

Figure 8. Distribution of Bank Credit to Private Firms in Zambia in 2005

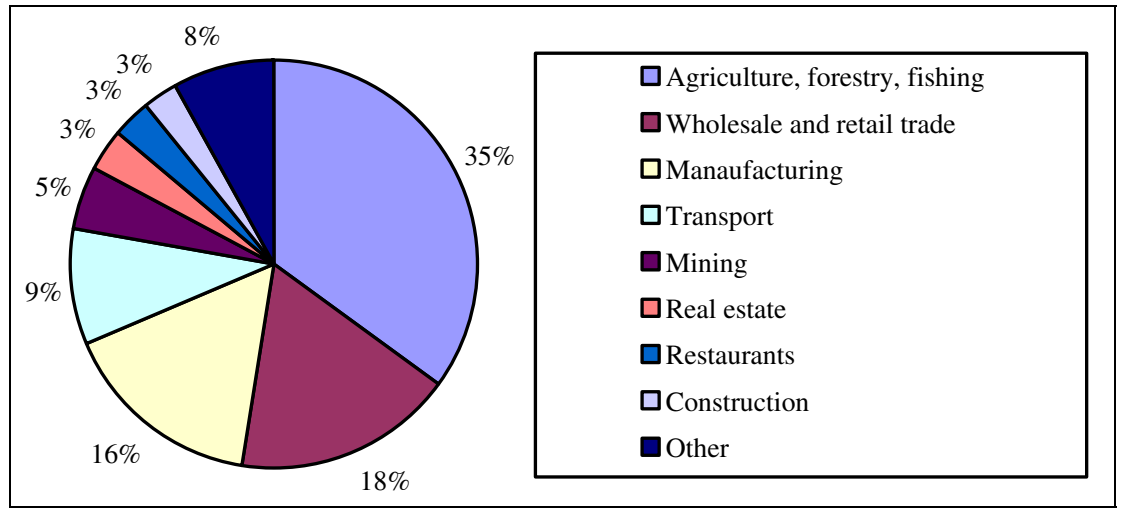

In Zambia, bank credit to private firms is not just scarce, but also extremely expensive. The average annual interest rate on loans was 48\% in 2005 (as compared to $20 \%$ inflation rate). Interviews with selected banks revealed that only large firms borrow at rates below the average (prime rate was 20\% in 2005). The few small and medium enterprises (SMEs) in Zambia which are able to borrow from banks pay the average annual lending rate. Given the exorbitant level of existing lending rates, most loans have a short-term 
maturity (1-3 months); there are only few loans with a maturity of 1 year or more. Those few firms with sources of revenue in foreign currency are able to obtain financing from banks in US dollars at lower interest rates.

With the exception of high-income households, public servants and employees of large companies, most Zambians do not have access to financing products offered by banks. Low salaries, lack of a job in the formal economy and high interest rates have precluded Zambian workers from having access to any type of consumer credit offered by the banking system.

In Zambia, most of the consumer lending consists of salary-loans. These are personal loans granted to employees of public institutions and large private firms. The monthly payment is directly deducted from the workers' salary by the employer and remitted to the banking institution. Other types of consumer credit, such as credit cards and loans to acquire vehicles, do not exist in Zambia. Mortgages are offered by a few banks, but the aggregate volume of mortgages is still extremely low.

The above developments have resulted in a financial system that serves only a few people and firms in Zambia. Historically, the banking sector has been unwilling to lend to the medium, small and micro sectors of the economy due to the high levels of risk associated with this sector. The harsh economic conditions that prevailed in the country in terms of high interest levels and volatile exchange rates meant borrowers found it difficult to repay their loans leading to poor repayment rates. The situation was exacerbated by the inefficient legal system which made it difficult to seek redress through the courts, besides which, the small value transactions made it uneconomical to do so.

\subsection{Role of micro-finance institutions (MFIs) in Zambia}

Unlike other countries in Sub-Saharan Africa where micro-finance institutions (MFIs) have grown by providing financial services to low-income households, in Zambia MFIs remain extremely small. According to data from the Association of Micro-finance Institutions of Zambia, MFIs only serve 50,000 customers, representing $0.005 \%$ of Zambia's population. The small size of MFIs in Zambia is unusual even in the context of other low-income countries where MFIs have achieved a larger outreach. Microfinance institutions are small, and all together do not represent more than $2 \%$ of the assets of banking institutions.

As noted above, MFIs are not authorized to take deposits from the public. As a result, their main sources of funds are the commercial banks and the donor community. Because of their low volume of operations and high operating costs, loans granted by MFIs have higher interest rates than those offered by commercial banks. Most households borrow only short-term (one month) from MFIs to meet family needs or short-term liquidity needs, in the case of firms. 
Figure 9. Assets of Micro-finance Institutions (as per cent of assets of all financial institutions)

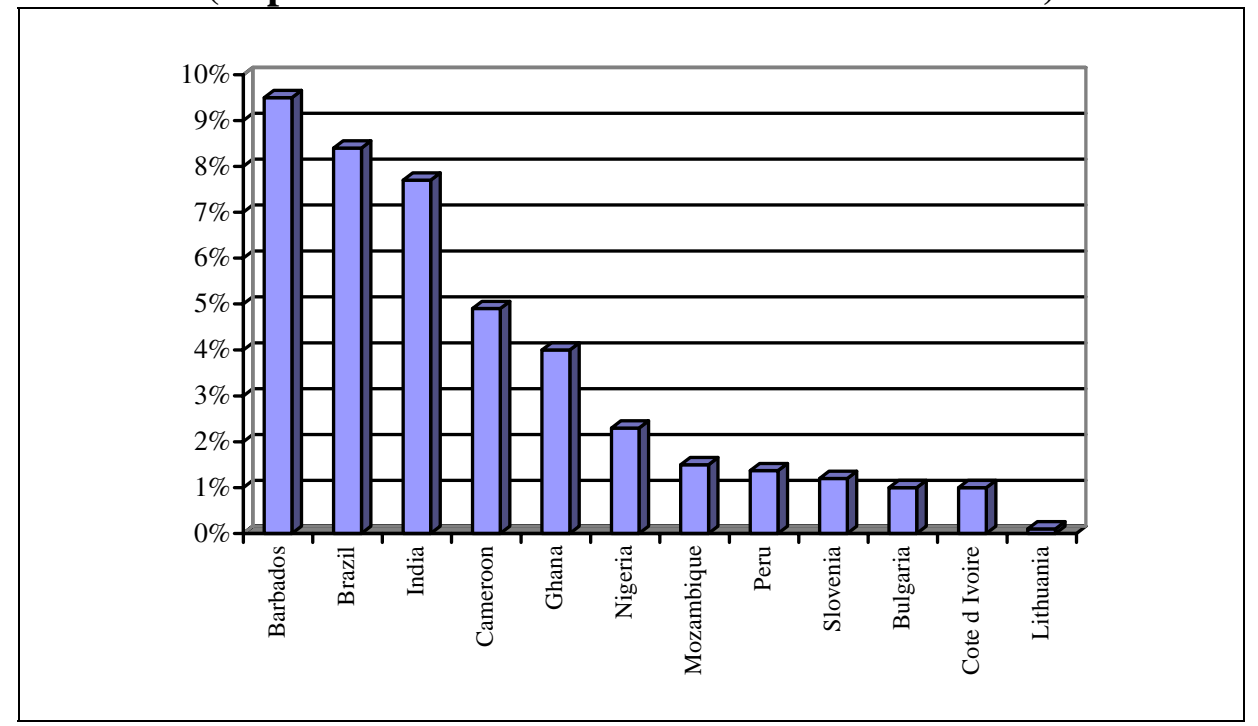

World Bank database on FSAPs.

During the past years, micro-finance institutions have suffered multiple problems. MFIs have failed to become self-sustainable and many do not meet basic reporting and financial disclosure requirements. Moreover, there have been instances in which the public has been defrauded by unscrupulous persons posing as MFI officers (see Chiumya 2006). To address these problems, authorities have designed a new regulatory framework for this type of financial institutions that would create two categories of MFIs, based on their size and capital. According to the new Banking and Financial Services (Microfinance) Regulations of 2006, the minimum capital for deposit-taking microfinance institutions is Kwacha 250 million (US \$78,125 dollars) and for nondeposit microfinance institutions is Kwacha 25 million (US\$7,812 dollars). The scope of permissible activities for MFIs would vary for each group of MFIs. Larger and more capitalized institutions would be allowed to take deposits from the public and lend, whereas smaller institutions would be allowed to lend, but not to take deposits from the public. Eventually, authorities expect the new regulatory regime will trigger a consolidation process among MFIs that will result in fewer but stronger micro-finance institutions in Zambia.

At this time, the major challenge for authorities is to put in place a regulatory framework that promotes the protection of people's money, transparency and sound governance of MFIs, and the growth and long term self-sustainability of the micro-finance sector. Critically important would be to establish rules on secured and un-secured lending, including a broad definition of "assets" that can be used by borrowers to pledge as collateral for their loans. These regulations should be aligned with the economic condition of MFI's clients in Zambia. Zambian authorities may wish to consider the experiences of successful cases of micro-finance, such as Jamaica, where MFIs serve $50 \%$ of the population on a sustainable basis. 


\section{Why Has Liberalization Not Delivered Benefits?}

There are various mutually-reinforcing factors that may explain the lack of growth and limited outreach of the Zambian banking system since liberalization, including:

- Inadequate sequencing of liberalization reforms,

- Insufficient economic growth, widespread poverty and few jobs in the formal economy,

- Crowding out of bank funds to finance the public sector, and

- Deficiencies in the basic infrastructure for financial sector development.

\subsection{Sequencing of liberalization reforms}

Following the prevailing development approach advocated by the international community in the early 1990s, Zambia - like many other developing countries transformed its closed and repressed financial system into an open and deregulated one. The problem is that this transformation was done without first building an effective legal, regulatory and supervisory framework which - combined with proper market incentives and monitoring - would encourage prudent risk-taking in banking institutions and ensure market discipline.

\section{Figure 10. Zambia. Sequencing of Financial Sector Reform}

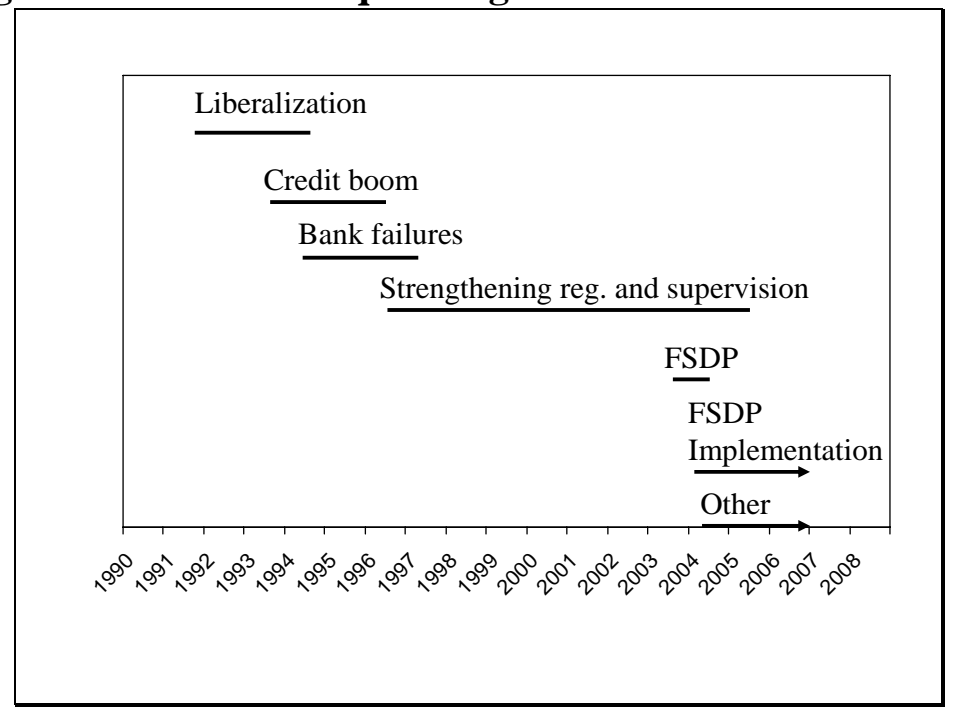

Following the liberalization measures of the early 90s, it became more attractive for private investors to establish new financial institutions and make high profits from lending and trading operations in foreign exchange and treasury bills. Additionally, 
minimum capital requirements for establishing banks become progressively low due to the depreciation of the kwacha. Ten bank licenses were issued between 1991 and 1994, with the number of commercial banks in operation increasing from ten in 1990 to eighteen in 1994, as illustrated in the following figure.

Figure 11. Zambia. Growth in the Number of Banks (1990-2004).

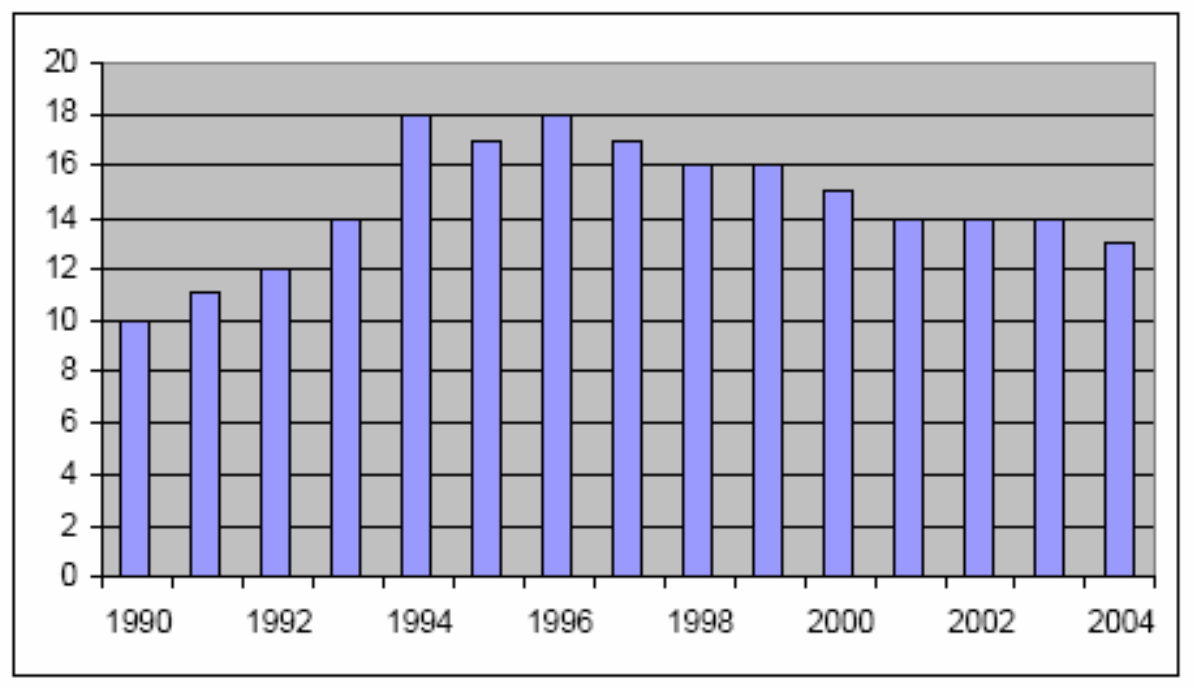

Source: Bank of Zambia

In the absence of an effective set of minimum prudential rules - in terms of proper loan classification and provisioning, internal controls, corporate governance, credit risk management, etc. - and lack of risk-management capacity within commercial banks, the liberalization process of 1992-93 led to a rapid growth of financial institutions, a credit boom - bank credit to the private sector increased from 4.7\% to $8.4 \%$ of GDP between 1993 and 1995 - and subsequently, a series of bank failures in 1995 and 1996.

Risky lending to attract new customers, lower revenue from foreign exchange operations, lower treasury-bill yields, periodic shortages of liquidity, and limitations to raise capital eroded the solvency of many banks, causing nine bank failures between 1995 and 2001 that brought enormous losses to taxpayers and depositors (approximately 7\% of GDP).

Bank failures had negative effects on the entire banking system, leaving a large stock of non-performing loans. At the end of 2005, NPLs in the banking system still amounted to $8.9 \%$ of total loan portfolio. Moreover, several banks scaled back their lending operations and increased their holding of government securities, which offered high yields at a lower risk for banks. Barclays, the largest bank in Zambia, refrained from any new lending for several years. It was only in 2006 that it started to lend again.

In addition, it is widely believed that the treatment of the management of failed banks was lenient. No legal action was taken in some cases of violation of banking laws, and some managers were allowed to take jobs elsewhere in the financial system. Failure to take strong measures against the questionable banking practices that led to bank failures 
and ineffective collection efforts has contributed to serious moral hazard and the widespread belief that misconduct in the financial sector would not be prosecuted.

As the Zambian crisis has shown, a different sequencing of reforms may have avoided some of the problems faced by the banking system in the 1990s. In particular, more efforts could have been put in strengthening the quality of regulation and supervision before liberalization is conducted.

Following the first episodes of bank failures in 1995, Zambia put in place major measures to improve the quality of bank regulation and supervision. Between 1995 and 2000, bank regulation and supervision was significantly strengthened. In 2002, the IMF and World Bank completed an extensive review of the financial system, conducted under the aegis of the Financial Sector Assessment Program (FSAP). In this review, it was found that Zambia satisfactorily complies with the Basel Core Principles on Bank Supervision, which constitute the most important international standard in bank regulation and supervision. Of the 30 principles assessed under the BCPs, Zambia was found to be compliant or largely compliant with 19 principles and non-compliant or materially noncompliant with 11 principles.

Major weaknesses were found in the areas of independence of the central bank, remedial measures to deal with insolvent banks, management and control of market risks, internal controls, and anti-money laundering. The Bank of Zambia has been working to address the deficiencies found in the FSAP assessment and much progress has been made, bringing regulation and supervision of banks closer to international standards.

There are many deficiencies in the legal and regulatory framework that still hold back financial sector development. Fortunately, authorities are showing enormous commitment to address them. Following the release of the FSAP report, authorities drafted a Financial Sector Development Plan (FSDP) which contains a series of actions for the period 20042010 to strengthen the overall financial system.

\subsection{Poor economic performance and macroeconomic environment}

Zambia, which until two decades ago was one of the most prosperous countries in SubSaharan Africa, now ranks as one of the least developed countries in the world. The poor performance of Zambia's economy over the past 30 years, as evidenced by the declining per capita GDP, has had a significant impact on the level of poverty in the country. In 2004, 73\% of the population was officially classified as poor (that is, below the national poverty line). Poor people do not have bank accounts either because there are no bank branches in their communities or because the minimum balances to open and maintain a bank account are extremely high, given their income level.

The situation has been exacerbated by the lack of jobs in the formal economy. Formal sector employment, which has not exceeded $20 \%$ of the labor force for a number of 
years, declined to 10\% from 12\% between 1996 and 2004. Following international standards on anti-money laundering and combat for terrorism financing, banks in Zambia have adopted guidelines that prevent them from providing services to customers that cannot be identified or cannot demonstrate their source of income. Although Zambians have national identification documents, many people can not proof their source of income.

A similar situation affects private sector firms in Zambia, in particular small and medium enterprises. There are no official statistics on the number of SMEs in Zambia, but it is believed that many of them are not registered, do not pay taxes, and do not have audited accounts. As a result, they can not access financial services - either savings, deposits, cash management, lending, guarantees, etc_-offered by banks.

An additional challenge faced by Zambia is related to the HIV/AIDS problem. Principally, HIV/AIDS threatens the country's capacity building efforts because it strikes the educated and skilled as well as the uneducated. Consequently it reverses and impedes the country's capacity by impacting human productivity and life expectancy. The long periods of illness of the skilled personnel in employment has translated into severe loss in economic productivity, which leads to considerable loss to the employer in terms of manhours. Nowadays, life expectancy in Zambia is only 36 years, largely due to the HIV/AIDS problem.

During the past years, banks in Zambia have operated in an environment characterized not only by low economic growth and falling per capita incomes, but also by high inflation, a large fiscal deficit, exchange rate volatility, and an external debt burden.

Table 3. Zambia. Select Macroeconomic Indicators, 1997-2005

\begin{tabular}{|l|c|c|c|c|c|}
\hline \multicolumn{1}{|c|}{ Indicators } & $\mathbf{1 9 9 7 - 2 0 0 1}$ & $\mathbf{2 0 0 2}$ & $\mathbf{2 0 0 3}$ & $\mathbf{2 0 0 4}$ & $\mathbf{2 0 0 5}$ \\
\hline Real GDP Growth & $2.4 \%$ & $3.3 \%$ & $5.1 \%$ & $5.4 \%$ & $5.1 \%$ \\
\hline Real per capita GDP growth & $0.2 \%$ & $0.9 \%$ & $2.7 \%$ & $2.9 \%$ & $2.6 \%$ \\
\hline Real Per Capita GDP* & $\$ 313$ & $\$ 325$ & $\$ 334$ & $\$ 343$ & $\$ 352$ \\
\hline Consumer prices* & $24.7 \%$ & $22.2 \%$ & $21.4 \%$ & $18.0 \%$ & $18.3 \%$ \\
\hline $\begin{array}{l}\text { Overall fiscal balance, including } \\
\text { grants (in percent of GDP) }\end{array}$ & $-4.4 \%$ & $-5.1 \%$ & $-6.0 \%$ & $-3.0 \%$ & $-2.3 \%$ \\
\hline Trade balance (in percent of GDP) & $-5.0 \%$ & $-6.9 \%$ & $-7.2 \%$ & $1.5 \%$ & $0.8 \%$ \\
\hline $\begin{array}{l}\text { External debt to official creditors } \\
\text { (in percent of GDP) }\end{array}$ & $181.6 \%$ & $135.4 \%$ & $107.9 \%$ & $77.8 \%$ & $54.3 \%$ \\
\hline $\begin{array}{l}\text { Nominal effective exchange rates } \\
\text { (Index, 2000=100) }\end{array}$ & 127.0 & 85.4 & 70.8 & 69.0 & 78.6 \\
\hline
\end{tabular}

*In US\$ Dollars, at 2000 prices, using 2000 exchange rates

**Annual average percent change

Between 1997 and 2001, inflation in Zambia averaged 24.3\%, which was largely caused by the fiscal deficit, the high growth of money supply and depreciating Kwacha, and occasional shocks such as the effects of drought. A significant fall in inflation requires, among other things, a reduction in the government's budget deficit, which will reduce its need to borrow from domestic markets to finance the deficit. 
For many years, persistent fiscal indiscipline led the government to increase its reliance on domestic borrowing for funds. As a consequence, loans currently represent about onethird of total assets only, while total deposits are equivalent to about 70 percent of assets. High Treasury bill rates with their zero risk weighting for capital requirements and use in the MLAR have induced banks to hold large amounts of government securities. This concentration is especially high for small banks, with security holdings equivalent to $1 \frac{1}{2}$ -2 times of outstanding loans. Foreign exchange liquidity is also relatively high, as banks lend only about 20 percent of foreign exchange deposits, compared with kwacha loans equivalent to 70 percent of deposits.

Deposits raised by banks in Zambia are not just used to purchase government securities, but they are also placed in foreign institutions abroad, as illustrated in Figure 9. In 2002, $26 \%$ of total bank assets were placed in instruments in other financial institutions outside Zambia. ${ }^{8}$ However, the trend toward using local deposits to purchase government securities or invest overseas has reversed in recent years in favor of more domestic loans, as shown in the asset structure of banks in Zambia. Between 2002 and 2005, the share of loans in the total assets of banks increased from $19 \%$ to $30 \%$.

Figure 12. Zambia. Balance Sheet Structure of Banks 2002-2005

Assets

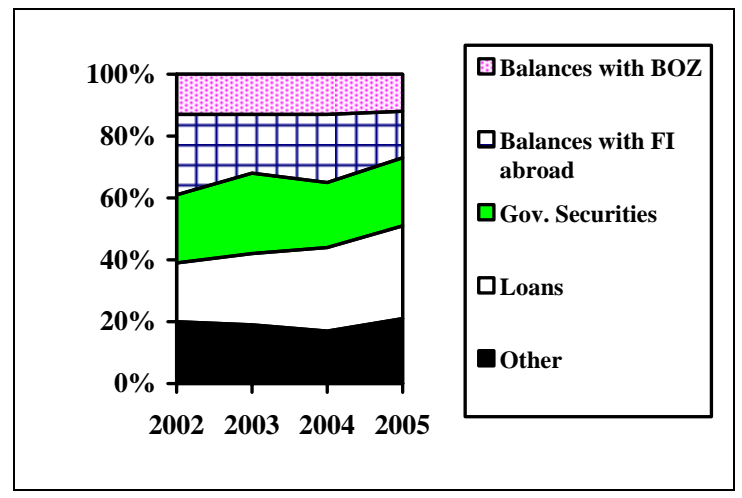

Liabilities and Shareholder's funds

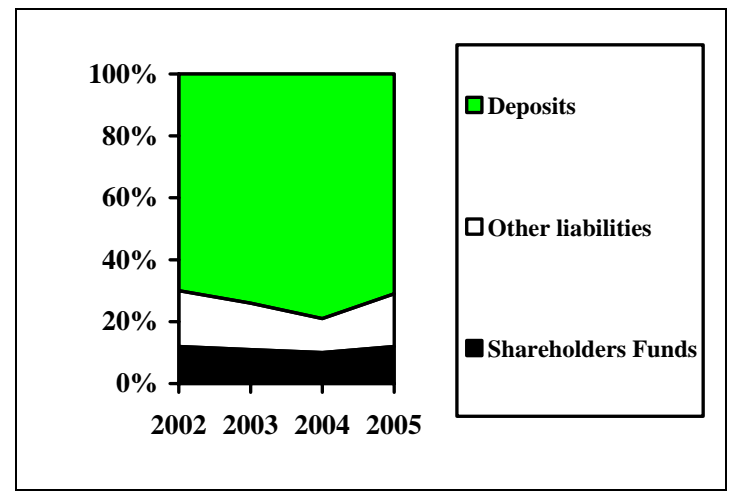

Source: Data from Bank of Zambia

The macroeconomic environment in Zambia has improved since 2004 when average annual inflation eased to $18 \%$, the first time in decades that annual price growth has been below 20\%. The fall in interest rates in the last couple of years, stabilisation of the exchange rate and reduction in domestic borrowing by Government has meant that banks are increasingly being forced to rely once again on their traditional source of revenue,

\footnotetext{
${ }^{8}$ There are many reasons why banks in Zambia, as well as in other countries in Africa, have large amounts of deposits abroad. First, they need to maintain these deposits abroad to finance imports as these are usually collateralized for letters of credits outside. Secondly, corresponding banks usually demand these balances to continue with corresponding relations. However, much more research is needed to determine the causes for the placement of deposits abroad.
} 
namely the provision of credit. This has resulted in various initiatives including the introduction of unsecured lending to salaried employees.

Since November 2003, interest rates on government securities have declined sharply. This is attributed to the following factors: The reduction in the statutory reserve ratio from $17.5 \%$ to $14 \%$ in October 2003; the reduction in Government borrowing; and the stability of the Kwacha against the US dollar due to the improvement in the external environment. With declining real interest rates on Government securities, commercial banks are expected to lower their own lending rates and increase credit to the private sector.

\subsection{Weak payment system infrastructure}

Financial sector development presupposes, among other requirements, a well functioning, efficient and reliable clearing and payments system. The payment system provides an essential conduit for the circular flow of money and execution of monetary policy. In addition, properly designed payments systems can contribute to financial system stability and promote access to banking and financial services. Over the years Zambia's National Payments System has had several weaknesses that contributed to undermining the development of the Zambian financial markets.

In the case of the cheque clearing system, for instance, the use of cheques has declined for a number of reasons including: high frequency of cheques issued against insufficient funds; delays in clearing funds on cheques; and poor and slow processing/operational systems in banks. The implication was that bank customers who were paid by cheque were at the mercy of their bankers. This situation also created huge amounts of float as a result of funds being tied up in the clearing process.

The BoZ has made significant progress in modernizing the payments system in Zambia by reforming the legal framework for payment systems, establishing electronic clearing, improving the security of cheque paper and introducing machine-readable cheques, as well as direct debit and credit clearing (DDACC) for payment of bills and salaries, and and a large value clearing system (real-time gross settlement system). The number of days for clearing a cross-country cheque has been reduced from 21 to 10 days while the inter-provincial and local clearing days were reduced to 6, 4 and 3 days, respectively.

Currently, the few banks with ATMs and points of sale (POS) terminals operate on an individual basis. Measures need to be developed and implemented that will ensure sharing of these facilities by payment system participants, including non-bank participants. 


\subsection{Deficiencies in the legal, regulatory and judiciary framework}

At this time, three issues require attention to promote financial sector development: the ineffective judicial system, the lack of credit information available, and the weak insolvency regime.

Zambia has a relatively well developed legal and judicial system compared with other African countries, but there is scope for improvement in several areas. The legal process has resulted in delays in the timely disposal of cases involving the collection of bad loans. Collection efforts have been weak for defaulters in public financial institutions, as well as in failed banks. Failure to take strong measures against questionable banking practices that led to bank failures also contributed to serious moral hazard.

While the operation of the courts continues to attract criticism, the introduction of a Commercial List and the increased emphasis on mediation and arbitration as alternative dispute resolution mechanisms is welcome and has done much to refute complaints over delays in the handling of commercial disputes. Nevertheless, the financial community continues to attribute difficulties in collecting loans to legal procedures and the ease with which borrowers can block creditor efforts to collect delinquent loans.

Authorities have identified the following shortcomings of the legal and judicial system, which it is hoped will be addressed through the FSDP and with the support of the donor community:

- Delays in delivering judgments;

- Lack of reported judgments;

- Bureaucratic procedures leading to delays in the enactment of new laws;

- Fragmented laws relating to the financial sector;

- Lack of guidelines and directives under principal Acts;

- Lack of adequate legal framework for regulating foreign currency transactions;

- Lack of financial sector consumer protection laws;

- Inadequate skills for enforcement of the law relating financial crimes; and

- Tendency not to report financial crimes to the relevant law enforcement agencies.

The credit bureau being set up by the Bankers' Association is a critical step to improve market information and to strengthen the credit culture. The current plan is to start the credit bureau with negative information on defaulters. That effort should be supported and expanded as soon as technically feasible to include positive information. This will help clients with a clean credit history enjoy the expanding services and lower costs. Over time, an attempt should be made to extend the credit bureau database to small- and medium-sized firms on whom there is little information available, and who need to use their good credit record to supplement their limited collateral.

In the past, the collection efforts against defaulting borrowers in some public financial institutions, as well as failed banks, have been ineffective. In Zambia, it is widely believed that the treatment of the management of failed banks during the late 1990s was 
lenient. No legal action was taken in some cases where banking laws were violated, and some managers were allowed to take jobs elsewhere in the financial system. Failure to take strong measures against the questionable banking practices that led to bank failures and ineffective collection efforts has contributed to serious moral hazard and the widespread belief that misconduct in the financial sector will not be prosecuted.

The Bank of Zambia needs to develop more effective arrangements for dealing with bank failures. It should establish accountability for management of bad loans. A cumbersome process of liquidating insolvent banks has resulted in loan recovery difficulties, partly as borrowers' capacity to continue borrowing from the banking system does not seem to be affected by nonpayment to banks in liquidation.

\subsection{Need to adapt prudential requirements to Zambia's needs}

One of the growing challenges for Zambia is that the adoption and enforcement of a number of international standards of prudential regulation is in tension with the goal of increasing access for low-income households. Three particular regulations appear to be affecting negatively access to finance: (a) the zero-risk weighting on government securities, (b) enforcement know your customer rules (KYC), and (c) reform of collateralized-lending.

As discussed above, banks in Zambia prefer to buy government debt securities due to the zero-risk weighting of government securities (recommended by the Basel Capital Accord), and thus the need for less regulatory capital for banks. This situation is not just faced by banks in Zambia, but everywhere in Sub-Saharan Africa where banking sector claims on governments, as percent of total claims, have increased from $19 \%$ in the period 1990-94 to 26\% in the period 2000-04 (IMF, 2006).

Another regulatory constraint in increasing access to finance is related to know your customer rules (KYC) issued by Zambia as part of its efforts to join international efforts to prevent money laundering and terrorism financing. KYC rules require banks to strictly verify the identity of their customers and their sources of income. However, in a country with $90 \%$ of the work force in the informal economy, the requirement of income verification has become a major obstacle preventing the wider provision of banking services. While it is important for banks to know their customers and verify they have the capability to repay their loans, more flexibility is needed in Zambia terms of documents and practices used by banks in order to assess the creditworthiness of their prospective clients. 


\section{BOX 1. Testimony of the difficulties faced by a banker in serving low-income households in Zambia due to the know your customer rules (KYC)}

"[... KYC does not favor nor meet the needs of our poorer people to have access to finance. We are required to demand the following:

A utility bill, for example for water, electricity or telephone. Many Zambians live in areas where these facilities are either non-existent or the bills are in the name of someone else, such as a landlord. In order to avoid paying tax on the rental income, most landlords will not allow their bills to be used. The other reason for their reluctance is plain suspicion that they may be held liable for the borrowing, jealousy or the mobility of these tenants who change accommodation often as rates can be raised at any time.

In the rural areas and in the villages, all these documents do not exist but the chief or traditional ruler can verify that your address. Which financial institution will accept this proof? KYC does not give them the leeway to vary these rules as the Central Bank also enforces these rules and banks are rated on their compliance.

They also need passport size photos and copies of identity cards. The latter is available as it is a national requirement to have a registration card but photos in certain locations are difficult to obtain.

Banks also ask for a minimum balance in their deposit accounts. These minimum balances prevent people from using banks.

For small businesses, they must produce the documents asked for under the Companies Act or Societies Act or Co-operative Act. There are Certificates of Incorporation, certificates of registration as well as tax clearance certificates, trading licences and so on. These can all be obtained but need patience, some literacy levels to deal with the bureaucracy. There are different offices and ministries involved as well as fees at every point.

In the case of a pilot group of ten from the market here, we got them to provide their IDs and passport size photos and we then used our version of the group lending model by having them give a small deposit towards the loan individually, opening one account in their group name, and then giving them a lump sum each. The deposit was used to open the account as our minimum deposit was met and also acted as a commitment. They have since paid back two installments and they are on time and doing well. They have increased their stocks and got the council to give them a better location. We will increase the loan amounts once full repayment is made."

Source: Testimony of a commercial banker in Zambia. It is reproduced with the permission of the interviewed person. 
Several banks in Zambia have adopted guidelines that prevent them from recognizing movable assets as collateral. As a result, electro-domestic appliances and other types of movable assets - which constitute the main or only assets owned by the poor - cannot be pledged as collateral to obtain a loan. Moreover, unsecured lending is penalized through high provisioning requirements. As a result, the poor people can not access lending products from commercial banks.

While it is important to prevent money laundering activities, maintain the integrity of a banking system, and ensure that banks manage credit risks appropriately, the above regulatory requirements need to be revised to ensure that they do not prevent banks from serving low-income households in Zambia.

\section{6 Fragmented regional markets}

There are likely to be significant benefits from regional integration of financial services markets. A central consideration is that there are significant scale economies in banking, securities markets and payment systems. For instance, modern banks, insurance companies, pension funds, payments systems, and securities markets all use computerbased technology that is scale dependent for efficient operation. Even in their smallest configurations, these technologies often exceed the needs of institutions in small financial systems. As a consequence, larger financial markets tend to have an increased number of participants and are consequently more competitive. This leads to lower financial product pricing, increased access to finance, and increased levels of innovation than in smaller financial systems. An additional benefit is that in larger markets the regulatory infrastructure tends to be of higher quality and lower cost than in smaller markets. ${ }^{9}$

There is a spectrum of possible levels of financial integration. Some envisage an extreme situation in which all economies in Southern Africa have unified their financial systems which operate with a single currency, single monetary authority and a single regulator and supervisor. Others have a less ambitious view of regional financial sector integration, in which all financial sector institutions can operate across borders without facing any hurdle while maintaining domestic currencies and regulatory institutions.

COMESA has not made substantial progress in terms of financial integration. The treaty calls for the integration of financial structures and since 1999 member states have been working to harmonize their regulatory frameworks. The COMESA Bankers' Association has also been set up to exchange information and strengthen correspondent relationships among banks. However, Jansen and Vennes conclude that regional integration has not proceeded smoothly despite regulatory cooperation at the highest levels. ${ }^{10}$ In addition, they found that countries that were part of both COMESA and SADC were experiencing political problems and issues stemming from incompatible and overlapping legal

\footnotetext{
${ }^{9}$ For a fuller treatment of this, please see Regional Financial Sector Integration in Southern Africa: Issues and Opportunities, The World Bank, June 2006.

10 "Liberalizing Financial Services Trade in Africa: Going Regional and Multilateral", Marion Jansen and Yannick Vennes, WTO, March 2006, quoted in ibid, p.14.
} 
obligations. Hence, little progress has been made so far on these ambitious regional integration agendas.

Macroeconomic divergence is not by itself a reason to hold back from increased integration. Global financial markets provide a good example of how markets based in vastly different economies, in terms of macroeconomic balances, can be closely linked and in fact interdependent. Indeed, differences in economic prospects, different transactional cost structures and varying risk premiums usually influence the flow of capital and portfolio choices; and these differences can actually encourage financial transactions.

There are, however, economic and political concerns raised by integration in Southern Africa. On the issue of harmonizing financial infrastructure, for example, it has been noted that less developed countries of the region do not need to invest in sophisticated payment system architecture that will not be utilized in the foreseeable future. These countries should not give a high priority to developing regulatory frameworks and standards for certain financial instruments, such as synthetic products, and institutions, such as option exchanges. On the political side, policy makers have expressed their concern that "integration" in Southern Africa actually means "convergence" to South African structures, processes and ways in all areas and further domination by South African institutions.

Moving ahead, it is desirable to work towards creating better-integrated financial markets similar in terms of functioning to global financial markets as at least an interim point. Hence, the focus should be on creating an environment in which market participants have the same information set, same benchmarks and similar pricing mechanisms for different risks so that financial sector actors can take positions across countries without hurdles or prohibitive transaction costs. This would require that Southern African markets have a certain commonality, compatibility and inter-operability with respect to: a) physical infrastructure that provides timely and reliable trading and fund flow mechanisms; b) timely access to reliable data that conforms by and large to the same standards; and c) a well-understood and well-established dispute resolution mechanism with accompanying enforcement capabilities. 


\section{Pro-active Policies to Promote Access to Financial Services}

Promoting access to finance has proven to be a complex issue in Zambia, as well as in most developing countries. Since independence, Zambia has actively pursued policies to promote financial sector development - swinging from the extensive use of government controls on the financial system in the 1970s and 1980s to the establishment of a marketfriendly environment and deregulated financial system in the 1990s - in both cases with disappointing results.

A larger and more inclusive banking system is needed to alleviate poverty and establish the foundations of sustainable economic growth and development of Zambia. Sound and efficient banking institutions mobilize savings and channel them to productive uses, allowing firms to reach their growth potential and improving productivity. Moreover, inclusive financial institutions open up opportunities for energetic and able entrepreneurs. They enable people to smooth consumption and help households and firms manage their risks.

The financial services needed by poor households and small enterprises in Zambia include not only credit, but the simple and essential tools of a safe and low-cost way of saving, efficient payment and remittance services, and affordable insurance against the numerous hazards they face.

It is important to recognize that there are no "magic bullets" that will rapidly resolve the limited supply of financial services in Zambia. Efforts are needed on various fronts to remove the obstacles and bottlenecks that drag on the growth of the banking system, including the establishment of a credit bureau, modernization of the payment system, strengthening of the legal and judiciary framework, promotion of market discipline, establishment of efficient mechanisms for resolution of bank failures, strengthening of bank supervision, etc.

In addition to the above financial sector reforms, efforts are needed to preserve macroeconomic stability, reduce the fiscal deficit, improve the business environment, create new jobs in the formal economy, raise the average income of households and reduce the number of firms operating in the informal economy. Thus, a combination of further financial sector reforms, macroeconomic stability, and a better business environment is needed for a deeper and more efficient banking system that helps promote economic growth and prosperity in Zambia.

In the short-term, however, a relevant question for Zambia and the donor community is whether government intervention to foster financial development and broaden access is necessary and, if so, what form should this intervention take.

At an international level, there seems to be an increasing consensus (see De La Torre, et al 2006) that there is indeed a market friendly role for the visible hand of the government to promote access in the short run, while the fruits of ongoing institutional reform are still 
unripe. The important qualifier is that the government needs to be highly selective in its interventions, always trying to ensure that they work with the market, never against it.

\subsection{Instruments that distort the functioning of markets often either fail to improve access to services or do so at a high cost in terms of efficiency}

This has been the case with credit guarantee systems both in Zambia and elsewhere. Credit guarantee systems are mechanisms in which a third party, the guarantor, pledges to guarantee loans to a particular group of borrowers. Credit guarantee systems reduce the lender's expected credit losses — even if the probability of default remains unchangedacting as a form of insurance against default. Around the world, public credit guarantee systems are widespread. The largest and more established guarantee schemes are mostly in developed countries, including Canada, Japan, the U.S., and several European countries. The general experience with credit guarantee systems, especially in developing countries, has been poor to mixed: most systems have depleted their reserves due to high credit losses and bad investment decisions and in many cases they have been designed to channel funds to certain sectors without due regard to loss rates.

\section{Box 2. Credit Guarantee Scheme Operations in Zambia (1987-1993)}

The Zambian Credit Guarantee Scheme (CGS) was set up in 1987 and was operated by the Bank of Zambia. The Scheme had the objective of providing protection to financial institutions against losses incurred for credit exposures to small enterprises. The fund was financed from the net profits of Bank of Zambia with a view to have it become self supporting in the 'shortest' time practicable. Honoring of any guaranteed exposure to a financial institution was to be made upon the Bank of Zambia being satisfied that at the time such loan was made or funds advanced, financial institutions acted in good faith and in accordance with good banking practice.

The Scheme even though well intended faced problems on two frontiers. First there was general apprehension with having the Bank of Zambia back the credit guarantee scheme. Ideally such activities would be more appropriately placed under a development banking institution. Second, an element of moral hazard was evident over time as borrower repayment rates deteriorated. This was partly on account of the knowledge that such exposures were guaranteed by the central bank. To this extent therefore, the self sustainability of the fund in the longer term became questionable. Principally, because of these reasons, particularly the first, the credit guarantee scheme was abolished in 1993.

Critics of public credit guarantee systems also argue that these schemes cannot decrease asymmetric information problems in credit markets, and are even likely to increase them. Public guarantee systems may increase moral hazard for both borrowers and lenders: borrowers who know that their loans are guaranteed by the government may not feel obligated to repay them and lenders may have fewer incentives for screening and monitoring borrowers, as guarantees cover their credit losses. An open question therefore is whether credit guarantee systems can be designed in a market-friendly way, 
minimizing their unintended consequences while at the same time promoting private financial market activity.

However, if programs are well designed to reach their target, and if there is the institutional capacity to implement the project and avoid political capture, they can have an equalizing effect. This was demonstrated with both the Enterprise Development Program and the activities of the marketing board in Zambia.

Despite the widespread acknowledgment of the failure as a sustainable of Lines of Credit as means of increasing access, the Enterprise Development Project in Zambia EDP may be an example of how financial intermediary lending can have a positive impact in terms of providing scarce medium term lending for investment and export production to small and medium sized enterprises. ${ }^{11}$ Under this project, the funds were channeled through Bank of Zambia, but measures were put in place to strengthen Bank of Zambia's capacity to monitor the on-lending and successfully resist political pressures to capture the funds. In addition, the facility allowed local banks to freely decide on-lending rates, thereby allowing competition between banks receiving funds from the project. ${ }^{12}$

\subsection{New instruments attempt to reconcile equity with efficiency}

Soft and hard commands on providers can work, but they must be designed realistically and flexibly, to allow the private sector to choose the most efficient and sustainable means of extending access. In South Africa, in response to government "moral suasion", the representatives of the financial services industry signed the Financial Sector Charter in 2003 in which they undertook to increase the number of poorer people (LSM1-5) with a bank account from $32 \%$ to $80 \%$ in 2008 . In order to achieve this goal the key players in the sector have collaborated to design the Mzansi account, which offers fewer services, but with cheaper charges on transactions, such as cash deposits and ATM withdrawals. The product has been highly successful with 180,000 new customers in the first six weeks. Thus, government pressure has pushed banks to innovate and to engineer a product which allows downscaling to be sustainable and even profitable. This example underlines that allowing banks to decide on the extent, process and technology of the expansion not only avoided conflict with the regulator, but also resulted in the kind of innovation and sector wide coordination necessary to achieve the set objective.

\subsection{Access to financial services might be better attained by exploiting the synergies between services sectors in order to increase the likelihood of achieving access goals}

Given that banks have found it a challenge to move profitably downscale because of the nature of demand in poorer and rural areas, which is small in scale, but transaction intensive, there has been a move in many countries towards "correspondent banking" as a way to broaden the range of delivery points and allow for small scale banking. Banks

\footnotetext{
${ }^{11}$ OED Review of Bank Lending for Lines of Credit, May 6 2004, iii

${ }^{12}$ Implementation Completion Report on a Credit for an Enterprise Development Project, The World Bank, December 2003.
} 
outsource services typically undertaken at branches, like receiving loan applications, making deposit withdrawals, and paying invoices, to non-financial institutions with a significant network of outlets, such as convenience stores or lottery houses. In Zambia, banks could achieve this through the use of the postal network. This has been highly successful in Brazil, for example, where it was estimated that the cost of providing banking services through the already existing post office was $0.5 \%$ that of building a new branch. ${ }^{13}$ However, building effective and strong partnership between state-owned postal operators and financial institutions has proven to a complex and cumbersome process as the divorce of Zampost and the National Savings and Credit Bank underlines. A recent report on lessons for expanding access to financial services through the postal networks highlights two particular weaknesses that have undermined the potential for publicprivate partnerships: first, private banks are loath to work with an institution which is not run on a commercial basis, is dependent on a non transparent provision of subsidies between the separate services being offered by the Post Office and which has little tradition of accountability. ${ }^{14}$ The second problem is that there has been a lack of investment in ICT in many postal networks in Africa which is again an argument for bundling access to postal and banking services with access to telecommunications networks.

If services are effectively bundled they will benefit from the positive spillovers of joint consumption. This is the approach underlining the recent "Zyonse" product that has been developed by the National Resources Institute to be offered to smallholder farmers in Zambia. The financial product offered is a package which consists of the following: insurance, primarily covering weather insurance; production credit and collaterization of produce to improve crop marketing as well as ease access to commodity finance. The product is to be offered by financing banks, with the insurance cover provided by credible insurance companies. Farmers ultimately pay the insurance premium, but it may be initially financed by the banks. The loan covenants require farmers to deposit and market their produce using the warehouse receipt system. ${ }^{15}$

In general, bundling of services will create a significant regulatory challenge to ensure competitive and cost-based access to shared networks - the problem that motivated some of the separations. If banks are to use the postal network, they must continue to remain institutionally separate from the Post, coming under the central bank supervision. Regulating access to networks has proved to be a challenge even within a single sector. In South Africa, incumbent banks have been accused of erecting barriers in the payments system against smaller banks wishing to introduce new technologies. ${ }^{16}$ In Zambia, Zamtel does not provide cost-based access to its fixed line network, thus limiting competition in the internet sector. The problems will be greater if multiple services are

\footnotetext{
${ }^{13}$ Schmukler, S. And Gozzi, J.C., Innovative Experiences in Access to Finance: Market Friendly Roles for the Visible Hand?, The World Bank, April 2006.

${ }^{14}$ The Role of Postal Networks in Expanding Access to Financial Services, The World Bank, Jan 2006.

${ }^{15}$ Onumah, Gideon, Feasibility of introducing an all-inclusive financial product in Zambia to improve access to rural finance, National Resources Institute, 2005

${ }^{16}$ South Africa: technology and Access to financial services, p.53
} 
to be provided from the same network but the potential benefits in terms of access provide good reason to look for solutions.

While the specific form of intervention is an issue that needs to be analyzed and discussed in a separate document, it is important to keep in mind that interventions should be relatively small and temporary, being terminated when the underlying causes of the problem of access have been removed. There must also be mechanisms in place to prevent political capture that may undermine the temporary nature of the interventions or their compatibility with the long-run objective of institutional reform and financial market development. Pro-market activism should favor a policy strategy that explicitly creates room for a process of discovery and learning-by-doing as the interventions are implemented, and may be useful to give the authorities a first hand understanding of what legislation or enforcement mechanisms are missing for certain innovations to take off. The ultimate goal is to foster the broadening of access in ways that simultaneously create financial markets where they are missing or enhance the functioning of the existing ones. 


\section{REFERENCES}

Chiumya, Chiara (2004): Banking Sector Reform and Financial Regulation: It's Effects on Access to Financial Services by low Income Households in Zambia. Paper presented to the 3rd International Conference, "Pro-Poor Regulation and Competition: Issues, Policies and Practices, 7-9 September 2004 in Cape Town, South Africa

Chiumya, Chiara (2006): The Regulation of Microfinance in Zambia. Washington, DC, CGAP, Essays on Regulation and Supervision.

Consultative Group to Assist the Poor [CGAP] (2006): Access for All. Washington, DC, CGAP.

De la Torre, Augusto, Juan Carlos Gozzi and Sergio L. Schmukler (2006): Innovative Experiences in Access to Finance: Friendly Roles for the Visible Hand? Washington, DC, World Bank, manuscript, April 2006.

Detragiache, Enrica, Thierry Tressel, and Poonam Gupta (2006): Foreign Banks in Poor Countries: Theory and Evidence. Washington, DC, IMF Working Paper 06/18

IMF (2006): Regional Economic Outlook. Sub-Saharan Africa. Washington, IMF.

Kumar, Anjali (2005): Access to Financial Services in Brazil: A Study. Washington, DC, World Bank.

Maimbo, S. (2002) Explaining Regulatory Failure in Zambia Journal of International Development, 14, 229-248.

Martínez Pería, María Soledad, A.Demirgüç and T. Beck (2005): Access to and use of banking services across countries. Washington, DC, World Bank Policy Research Paper.

Onumah, Gideon, Feasibility of introducing an all-inclusive financial product in Zambia to improve access to rural finance, National Resources Institute, 2005

OED (2004) Review of Bank Lending for Lines of Credit, The World Bank, May 62004.

Zambia. Financial Sector Development Plan, 2004-2009. Lusaka, Zambia, 2004.

World Bank (2003), Implementation Completion Report on a Credit for an Enterprise Development Project, The World Bank, December 2003.

World Bank (2004), South Africa: Technology and Access to Financial Services, The World Bank, 2004.

World Bank (2006a), Regional Financial Sector Integration in Southern Africa: Issues and Opportunities, The World Bank, June 2006.

World Bank (2006b), The Role of Postal Networks in Expanding Access to Financial Services, The World Bank, Jan 2006. 


\begin{tabular}{|c|c|}
\hline \multicolumn{2}{|c|}{ Annex 1. Banks Licensed in Zambia (1906-1994) } \\
\hline Name of Bank & Year of Incorporation \\
\hline 1. Standard Chartered Bank & 1906 \\
\hline 2. Barclays Bank & 1918 \\
\hline 3. Stanbic Bank & 1956 \\
\hline 4. Zambia National Commercial Bank & 1970 \\
\hline 5. Citibank & 1979 \\
\hline 6. Meridien Bank BIAO* & 1984 \\
\hline 7. Indo-Zambia Bank & 1984 \\
\hline 8. African Commercial Bank* & 1984 \\
\hline 9. Finance Bank & 1984 \\
\hline 10. Manifold Investment Bank* & 1987 \\
\hline 11. Zambia Export and Import Bank* & 1987 \\
\hline 12. Cooperative Bank* & 1989 \\
\hline 13. Commerce Bank* & 1989 \\
\hline 14. Union Bank* & 1991 \\
\hline 15. Cavmont Merchant Bank & 1992 \\
\hline 16. First Alliance Bank & 1992 \\
\hline 17. New Capital Bank & 1992 \\
\hline 18. First Merchant Bank* & 1992 \\
\hline 19. Mercantile Bank* & 1993 \\
\hline 20. Meridien Financial Services* & 1993 \\
\hline 21. Ital Bank* & 1993 \\
\hline 22. Continental Bank* & 1993 \\
\hline 23. Safe Deposit Bank* & 1993 \\
\hline 24. Prudence Bank* & 1994 \\
\hline 25. Credit Africa Bank* & 1994 \\
\hline
\end{tabular}

Annex 2. Banks in Liquidation

\begin{tabular}{|ll|r|}
\hline \multicolumn{1}{|c|}{ Name of Bank } & Liquidation date \\
\hline 1. & Meridien Biao Bank Zambia Limited & September 1995 \\
\hline 2. & African Commercial Bank Limited & February 1996 \\
\hline 3. & Zambia Export Import Bank Limited & May 1997 \\
\hline 4. & Prudence Bank Limited & February 1998 \\
\hline 5. & Credit Africa Bank Limited & March 1998 \\
\hline 6. & Manifold Investment Bank Limited & March 1998 \\
\hline 7. & First Merchant Bank Zambia Limited & March 1999 \\
\hline 8. & Commerce Bank Limited & January 2001 \\
\hline 9. & Union Bank Zambia Limited & March 2001 \\
\hline
\end{tabular}

